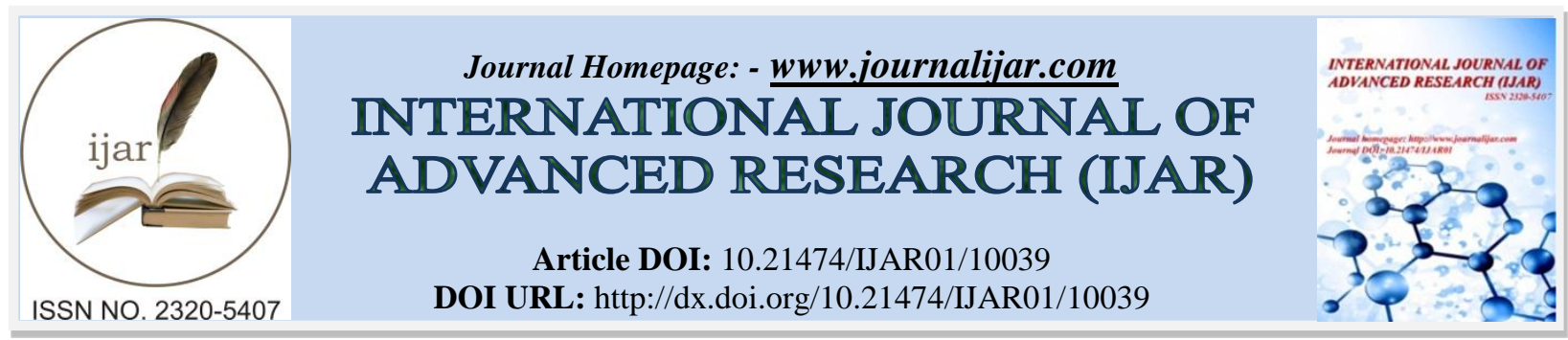

RESEARCH ARTICLE

\title{
DYNAMIC MODELLING OF QUALITY RICE STOCK IN KARAWANG REGENCY.
}

\section{Ekaterina Setyawati ${ }^{1}$, Sukardi $^{2}$, Yandra Arkeman ${ }^{2}$ and Muslich ${ }^{2}$.}

1. Student of Doctoral Program of Departement of Agroindustry Technology, Bogor Agricultural University , Bogor, West Java, Indonesia.

2. Lecture of Departement of Agroindustry Technology, Bogor Agricultural University, Bogor,West Java, Indonesia.

\section{Manuscript Info}

Manuscript History

Received: 10 September 2019

Final Accepted: 12 October 2019

Published: November 2019

Key words:-

Dynmic System, Quality Rice Stock , Karawang Regency

\section{Abstract}

The aim of this study is to find out rice stock which classified based on quality in Karawang Regency. Approaching simulation model with PowerSim used in this study. Results of the study showed that dynamic modeling of rice stock in Karawang Regency consisted of two submodel were consumption and production. Relationship between submodels was depicted in a form of causative diagram. Causative relationship (causal diagram) showed that there was positive feedback Model simulation with combined scenario, such as increasing yield production in rice milling and the level absorption grain paddy, is needed to maintaning the quality rice stock in Karawang Regency.

Copy Right, IJAR, 2019,. All rights reserved.

\section{Introduction:-}

Rice is a major food commodity and is one of the main commodities involved in the Ministry of Agriculture's four success programs. Rice is needed by more than $90 \%$ of Indonesia's population. Untill now Today's rice requirements cannot be met from domestic production so Indonesia still imported rice.[ Prabowo, 2012] The policy objectives for improving stock rice are to increase domestic production capacity, reduce rice dependence and maintain quality rice [Hassan ZH, 2014],[Coyle et all 2011], [Bala, 2014]

Rice demand increasing along with population, economic growth, purchasing power and changes of market taste. The dynamic demand causes the increasing need of rice nationally, in terms of quality, quantity and variety.. Karawang one of big supplier for rice in West Java and becomes one of parameter area to indicate the food deficiency. The Location where close to Jakarta caused Karawang become one of the targeted for around Jabodetabek Reseller to supply. On the hand Karawang now has developed to become as industrial area. This caused poplation and economic growth. The impact community around Karawang was life style one of the impact was the increasing need of rice not only just quantity but quality too. Although based on data At total rice in Karawang District still fullfil the local demand of local and tends to be increasing a year, But it becomes a different case where it was classified base on the quality. Based on the literature there is no research or data about rice stock where it was clasified by quality.

This research find out to illustrate efforts to develop the availability of quality rice stock in Karawang Regency by adopting a dynamic system modeling approach. In this study, it can be seen how the projection of rice availability in 
which policy interventions are linked rice milling performance as the main factor of rice production is supported by policy interventions in managing rice milling. The results of this study can be used as recommendations for the development of rice supply in Karawang Regency in the future.

\section{Methods:-}

The quantitative method supported with qualitative method used tin this study. The quantitative dynamic model such were site selection, determination of reviewed objects, selection of respondents, selection of data type and source, and selection of key variables through prospective analysis. The model of rice supply availability based on the quality of rice in Karawang Regency will be built using dynamic system. The selection of this method is done taking into account the complexity of the phenomena in the study area. The model is built on two submodel based rice production sub-models and rice consumption sub-models which classified by quality of rice.

The selection of Karawang Regency was based on several considerations: (1) Karawang Regency is one of the region in West Java that is expected to be a region for national rice production (2) Karawang $\mathrm{Rgency}$ becomes an industrial area $\mathrm{n}$ have big risk depletion harvested area. The research was conducted from Desember 2016 until 2017.

Analysis methods used in this study were Dynamic system analysis with Powersim software. This approach used to design models of quality rice stock in Karawang, which consist of] (1) need analysis,(2) design a model which analysis of problems and potential through the causal loop method.(3) Formulation of the problem into mathematical form in the structure of the model. This step is done by changing the causal diagram into a flow diagram that can be understood by computer software that will be used so that it can know the dynamic behavior caused by the assumptions of the simulated model, (4) Model verification and validation to assess whether the model was acceptable for performance and construction , (5) sensitivity analysis The sensitivity of this model is reflected in the model's response to the stimuli provided and characterized by changes in the behavior or performance of the model [6].Model sensitivity tests are intended to illustrate the sensitivity of parameters, variables, and relationships between variables in the model.(6) Simulation analysis, done to test and evaluate the model, make predictions, and study the effects of changes in exogenic changers to endogenic changers in the model.[Kholil, 2014]

In this study, the model simulation period is from 2015 to 2025 to reflect the performance dynamics of rice supply availability in Karawang Regency. In this study, three scenarios will be developed: a) business scenario (BaU), in which the scenario provides a description of the phenomenon change with the parameters used in accordance with the current state of affairs or without the intervention of the model, b) a simple scenario, in which the scenario it provides an overview of the phenomenon change if the intervention is performed on the main parameters in a simple manner, and c) optimistic scenario, where it provides an overview of the change in the phenomenon if the intervention in the main parameter is optimal.

Evaluate model performance using statistical tests by comparing model output with absolute average value or Absolute Average Error (AME). Acceptable error of 0-10\% [Mohammadi, 2015].

\section{Result and Discussions:-}

The dynamic modelling to predicts the availability of quality rice stock

The early development of modeling with dynamic systems begins with the introduction of systems. The identification of the food independence development system is built into the input output diagram or black box diagram. There are six groups of variables that influence system performance. These variables are grouped into controlled internal variables, uncontrolled internal variables, external goal variable, external undesirable variable and environmental internal variables.

Model prediction of quality rice stock in Karawang Regency based on two sub-models, consist of sub-model production model and sub-model demand. From the causal loop sub model as seen in figure 1, the relationship between variables is developed in the form of a stock flow diagram. The stock flow diagram in the dynamic model of rice availability prediction can be seen in Figure 2 . 


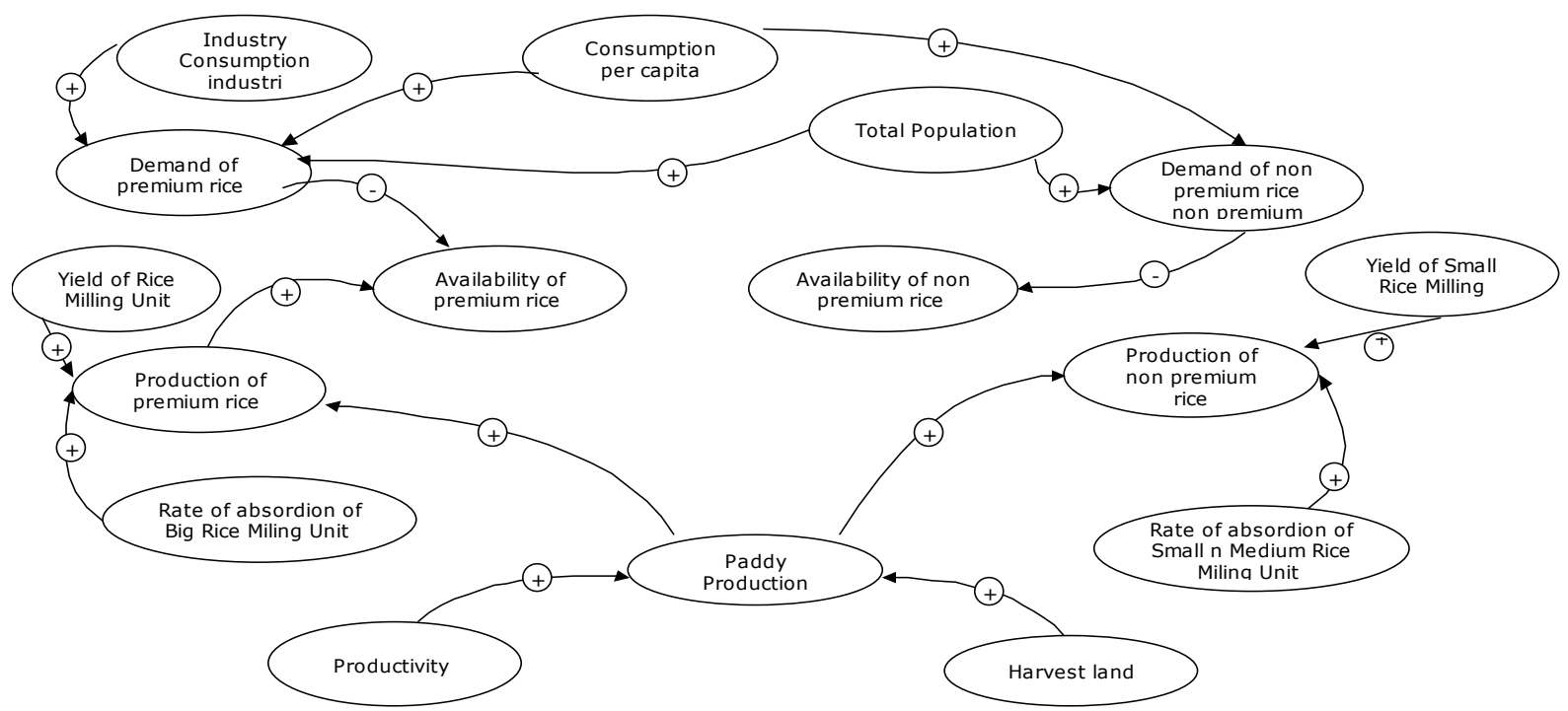

Figure 1:-Diagram causal loop of model prediction of quality rice stock in Karawang Regency

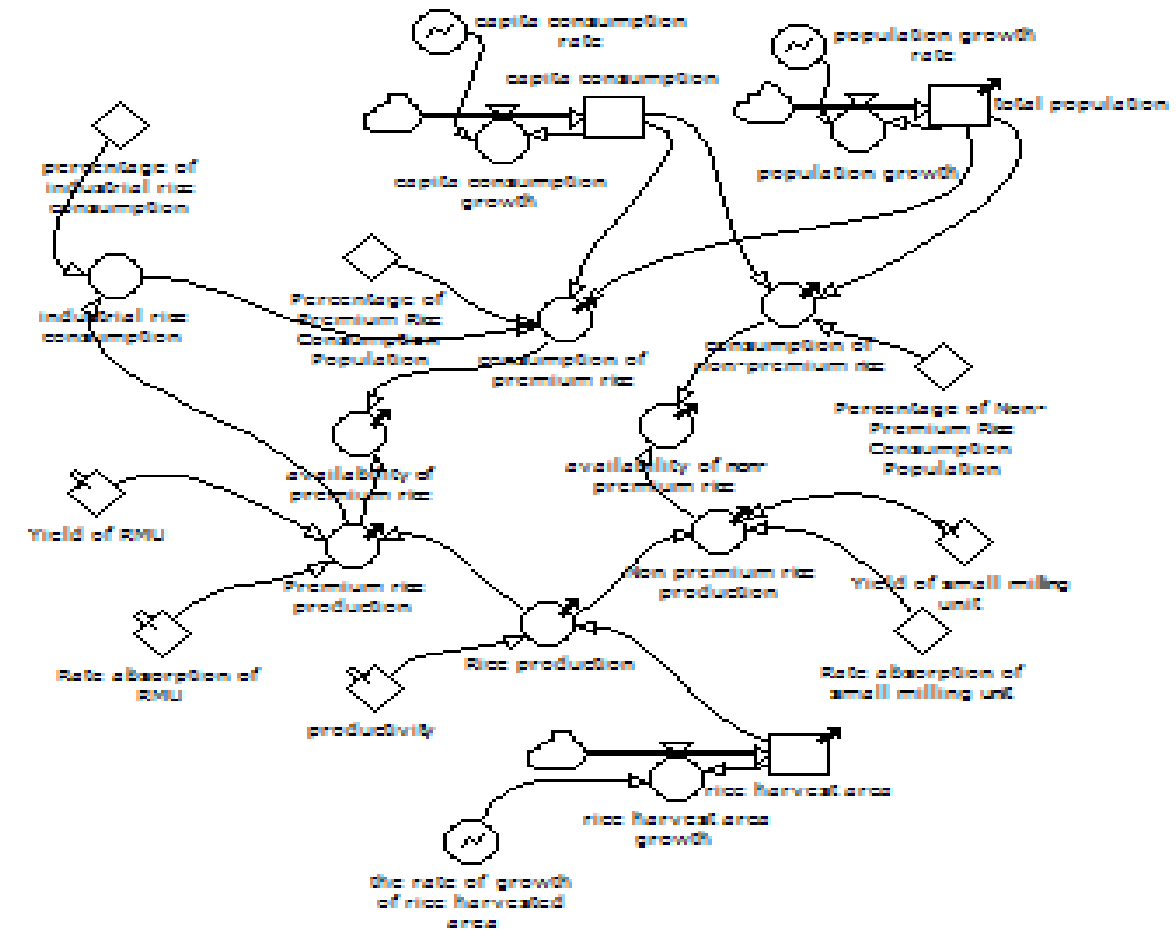

Figure 2:-Diagram Dynamic stock flow model prediction of rice availability in Karawang Regency

The next step is the validation and validation test performed to determine the suitability of the model made with the actual system [Kholil, 2014]. The method used in validating this model is to compare the model's behavior with its historical behavior. Modeling in dynamic system modeling can be done in a number of ways: direct structural testing, without operating models, model behavior testing (model-based behavioral testing) by operating models, and comparing model behavior with real systems.[Daelan , 2001] (quantitative behavior pattern comparison). This study conducts verification tests consisting of performance verification tests and structural verification tests. Performance validation tests were performed by comparing model behavior with actual performance during 2010 - 2016. The analysis showed that model performance compared to actual performance for all variables in each sub-model had AME values between the tolerance limit of $0-10 \%$. This shows a good level of validation for all sub models. The results of the variable validation in the model can be seen in Table 1 . 
Table 1:-Results of Verification of SubModel.

\begin{tabular}{|l|l|l|l|}
\hline No. & Model Components & AME (\%) & Description \\
\hline 1 & Per capita consumption & 1,5063 & Valid \\
\hline 2 & Population & 0,2349 & Valid \\
\hline 3 & Harvest Area & 1,005 & Valid \\
\hline
\end{tabular}

\section{Model simulations}

Model scenario variable is used were yield of Rice Milling and the level absorption of rice Milling. Rice milling become a target because one of affected the quality of rice was Rice Milling. [Budijanto, 2011]. Model simulations depicting the behavior of the models in this study are divided into three model scenarios, namely: (1) normal (current) scenario, (2) moderate scenario, and (3) optimistic scenario. The variable which be simulated was the level of yield at rice milling unit and the level absorption paddy grain in rice milling. The simulation is carried out with the assumption: (1) Normal (current ) scenario , for the existing yield conditions for all rice milling was $60 \%$, the rice mill absorption rate $1 \%$ for premium rice and $99 \%$ non-premium rice. (2) Moderate scenario is assumed that all the yield in rice mills was $65 \%$, the grain paddy absorption rate of premium rice is $1 \%$ and non-premium rice is $99 \%$. (3)The optimistic scenario assumes that rice production in large mills is increase $70 \%$ while rice mills remain $65 \%$ and for grain absorption for premium rate $3 \%$ and $97 \%$ non-premium rice. The simulation results can be seen in Figures 3 and 4.

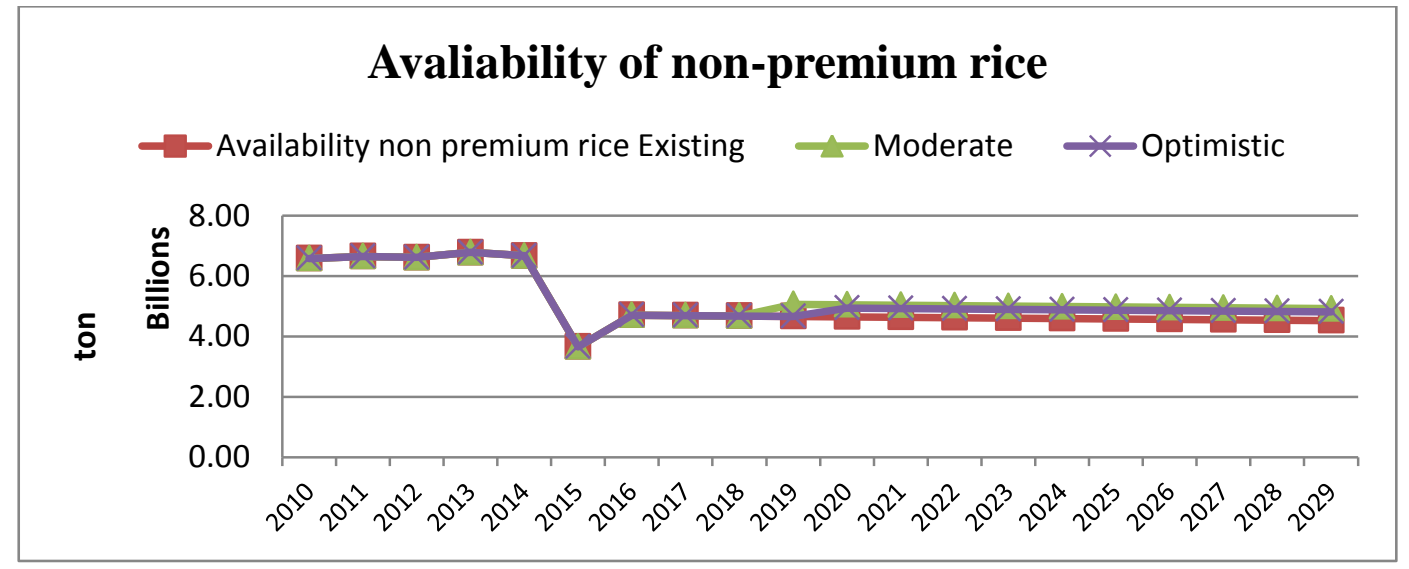

Figure 3:-Non-premium rice availability based on three scenarios

Simulation results for the availability of non-premium rice still have positive values, but from the trend there is a decrease, so treatment needs to be taken to reduce the deficit.

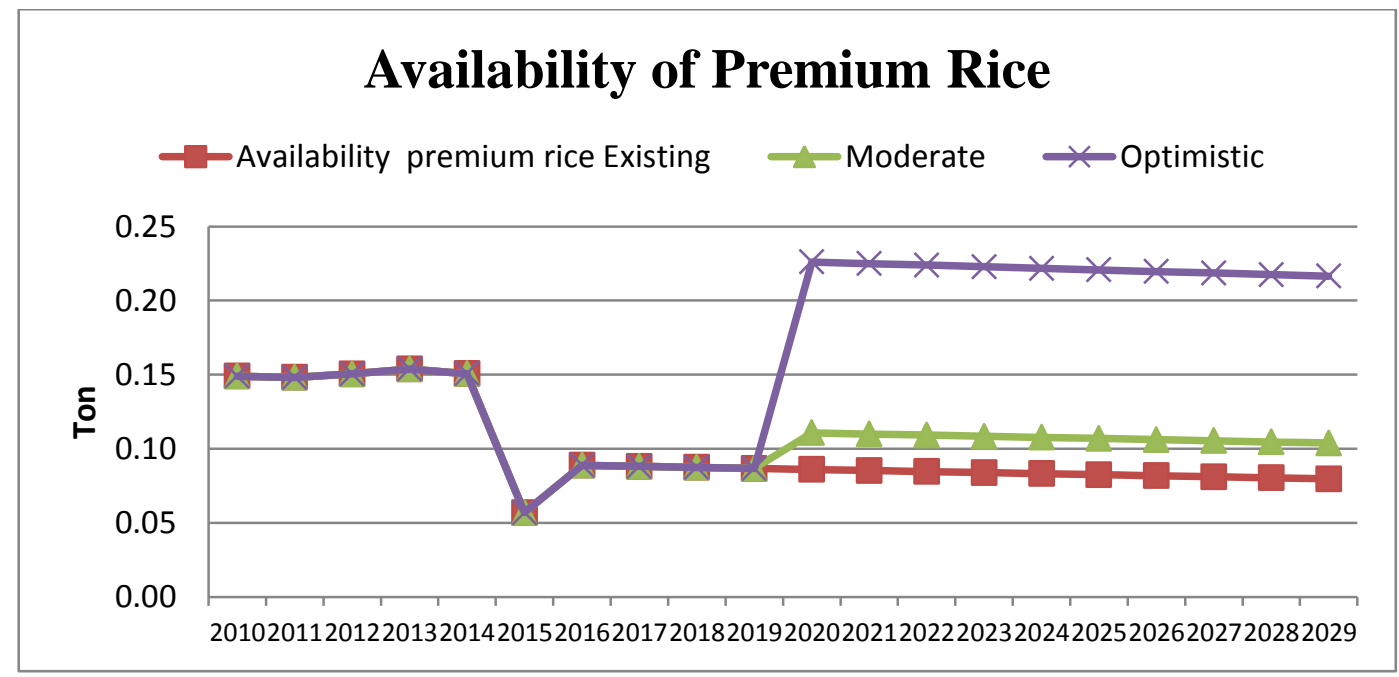

Figure 4:-Availability of premium rice based on three scenarios 
Simulation results for quality rice stock are seen as a deep decline. from 2016 to 2019 . These increases occur from 2020 to 2019 and are likely to remain. The increase in the availability of premium rice is mainly seen in optimistic scenarios.where there is treatment to increase the yield of Rice Milling unit and the grain paddy absorption in Big Rice Milling unit.

\section{Conclusions:-}

The result showed that the design of dinamic system can be applied to predict the availability of quality rice stock in Karawang Regency. The conclusions of the study are :

There is consist two submodel which develop to design model availability quality rice stock in Karawang Regency there are sub model production and consumption .Relationship between sub model were explain in the causal loop diagram. That there was positive feedback, which means that if this system is working by itself without external factors, rice stock will stagnan for non premium but for premium will decreased caused increasing demand (consumption). The reliability of this model can be verified by comparing simulation results with actual data. The common method used actual data from the previous year and compared it with simulation results, and the discrepancy should not have been more than 10 percent.

The prediction of quality rice stock can be achieved through dynamic and systematic approach by using optimistic scenario assuming that the yield produced by large rice milling is $70 \%$ and small rice milling by $65 \%$ with level absorption rate of rice milling to premium rice (quality) is $3 \%$ and $97 \%$ for non-premium rice.

This model can be used to control the system or as anticipation to changes of policies related to rice stock in Karawang Regency. It will be better to running the scenarios, such as revitalization rice milling, minimalizing rice consumption, or maintaining harvested area as the threat of maintaining quality rice stock in Karawang Regency in the future.

\section{Reference:-}

1. Bala BK, Alias EF, Arsha FM, Noh KM, Hadi AHA. 2014. Modelling food security in Malaysia. Simulation Model Practice and Theory $47: 152-164$

2. Budijanto dan Sitanggang 2011. Produktivitas Dan Proses Penggilingan Padi Terkait Dengan Pengendalian Faktor Mutu Berasnya

3. Coyle JJ, Novack RA, Gibson BJ, Bardi EJ. 2011. Transportation A Supply Chain Perspective. Kanada(US): Nelson Educaton, Ltd.

4. Daelan V, and W.A.H Thiessen. 2001. Dynamic Systems Modelling Continuous Models. Faculteit. Techniec, Bestuur en Management (TBM). Technische Universiteit Delft. Delft

5. Hassan ZH. 2014. Kajian rendemen dan mutu giling beras di kabupaten kotabaru provinsi kalimantan selatan. PANGAN. 23(3):232-243.

6. Kholil, Putri EIK, Listyarini. 2014. Pendekatan sistem. Jakarta: Universitas Jakarta

7. Mohammadi MF, Najafi A, dan Ahmadlo F. 2015. Using the analytical network process (anp) based on bocr model to select the most suitable region for forestation with almond species. Nusantara bioscience. 7(2):118127.

8. Prabowo A, Hermanto Y, Nugraha A, Somantri, Nurjaman, Susanti. 2012. Pengembangan Kebijakan Pertanian Mendukung Pencapaian Target Sukses Kementan 2014 Melalui Aplikasi System Modelling. Prosiding. 